Revista Destaques Acadêmicos, Lajeado, v. 9, n. 2, 2017. ISSN 2176-3070 DOI: http://dx.doi.org/10.22410/issn.2176-3070.v9i2a2017.1401 www.univates.br/revistas

\title{
TRADIÇÕES CULTURAIS AÇORIANAS E DE SEUS DESCENDENTES NA REGIÃO VALE DO TAQUARI, RIO GRANDE DO SUL/BRASIL
}

\author{
Cleidirose da Silva ${ }^{1}$, Luís Fernando da Silva Laroque ${ }^{2}$, \\ Neli Teresinha Galarce Machado ${ }^{3}$
}

Resumo: O estudo analisa elementos da cultura açoriana e de seus descendentes, considerando as tradições e a religiosidade, presentes na Região Vale do Taquari, Rio Grande do Sul/Brasil. O referencial teórico ancora-se em autores com foco em estudos culturais. O método de abordagem é o qualitativo e de conteúdo, utilizado no tratamento de fontes bibliográficas orais e documentais. $\mathrm{O}$ estudo, inicialmente, apresenta a colonização açoriana no Rio Grande do Sul e na Região Vale do Taquari, delimitando como recorte espacial, particularmente, os municípios de Taquari e de Paverama. Na sequência, e tomando como fio condutor os referidos municípios, analisam-se elementos culturais dos açorianos e de seus descendentes na Região Vale do Taquari, considerando aspectos gastronômicos, arquitetônicos e irmandades religiosas, com enfoque na procissão de Corpus Christi e nas festas em homenagem aos santos padroeiros das capelas e das igrejas.

Palavras-chave: Açorianos. Elementos Culturais. Região Vale do Taquari. Rio Grande do Sul.

\section{INTRODUÇÃO}

Os primeiros açorianos que chegaram ao Brasil, oriundos das "Ilhas dos Açores" com a esperança de melhores condições de vida, desembarcaram entre os meses de janeiro e fevereiro de 1748, em Santa Catarina. Desta localidade, partiram em embarcações menores, até o porto da Vila de Rio Grande, no Continente de São Pedro do Rio Grande do Sul. A política de distribuição

1 Graduada em História pelo Centro Universitário Univates. E-mail: cleidirose@yahoo.com.br

2 Doutor em História. Professor e pesquisador do PPG em Ambiente e Desenvolvimento e do Curso de História do Centro Universitário Univates, Lajeado. E-mail: Iflaroque@univates.br

3 Doutora em Arqueologia. Professora e pesquisadora do PPG em Ambiente e Desenvolvimento da Univates, Lajeado. E-mail: ngalarce@univates.br 
de terras em regiões brasileiras foi confusa e demorada. Muitos casais, sem receber a ajuda prometida, foram abandonados em áreas não colonizadas, onde, posteriormente, foram fundadas cidades como Porto Alegre, Mostardas, Estreito, Osório, Santo Amaro, Taquari, Rio Pardo e Gravataí.

Os primeiros colonizadores açorianos instalaram-se, provisoriamente, em Taquari, em 1760. A fundação da cidade ocorreu em 1764, com a instalação de 14 casais. Em 1770, já se encontravam no local mais 60 famílias açorianas. A colonização da região que atualmente pertence ao município de Paverama ocorreu no final do século XVIII, com a chegada de açorianos originários de Taquari.

O objetivo do estudo visa analisar elementos da cultura açoriana e de seus descendentes, considerando as tradições e religiosidade presentes na Região Vale do Taquari, Rio Grande do Sul/Brasil. O referencial teórico embasa-se em estudos culturais, dentre os quais selecionamos autores como Santos (1983), Geertz (1989), Barth (1998) e Eliade (2010). O método constitui-se numa abordagem qualitativa e de conteúdo, utilizadas no tratamento de fontes bibliográficas orais e documentais.

\section{A COLONIZAÇÃO AÇORIANA NO RIO GRANDE DO SUL E NA REGIÃO VALE DO TAQUARI}

A vinda dos imigrantes açorianos para o Brasil, mais especificamente para o Continente de São Pedro no Rio Grande do Sul (Figura 1), ocorre num contexto de transformações no espaço sulino, a fim de povoar regiões ditas ainda vazias, inicialmente, próximas ao Forte Jesus-Maria-José, atendendo às solicitações do rei de Portugal, D. João V. 
Figura 1: Mapa do litoral do Continente de São Pedro

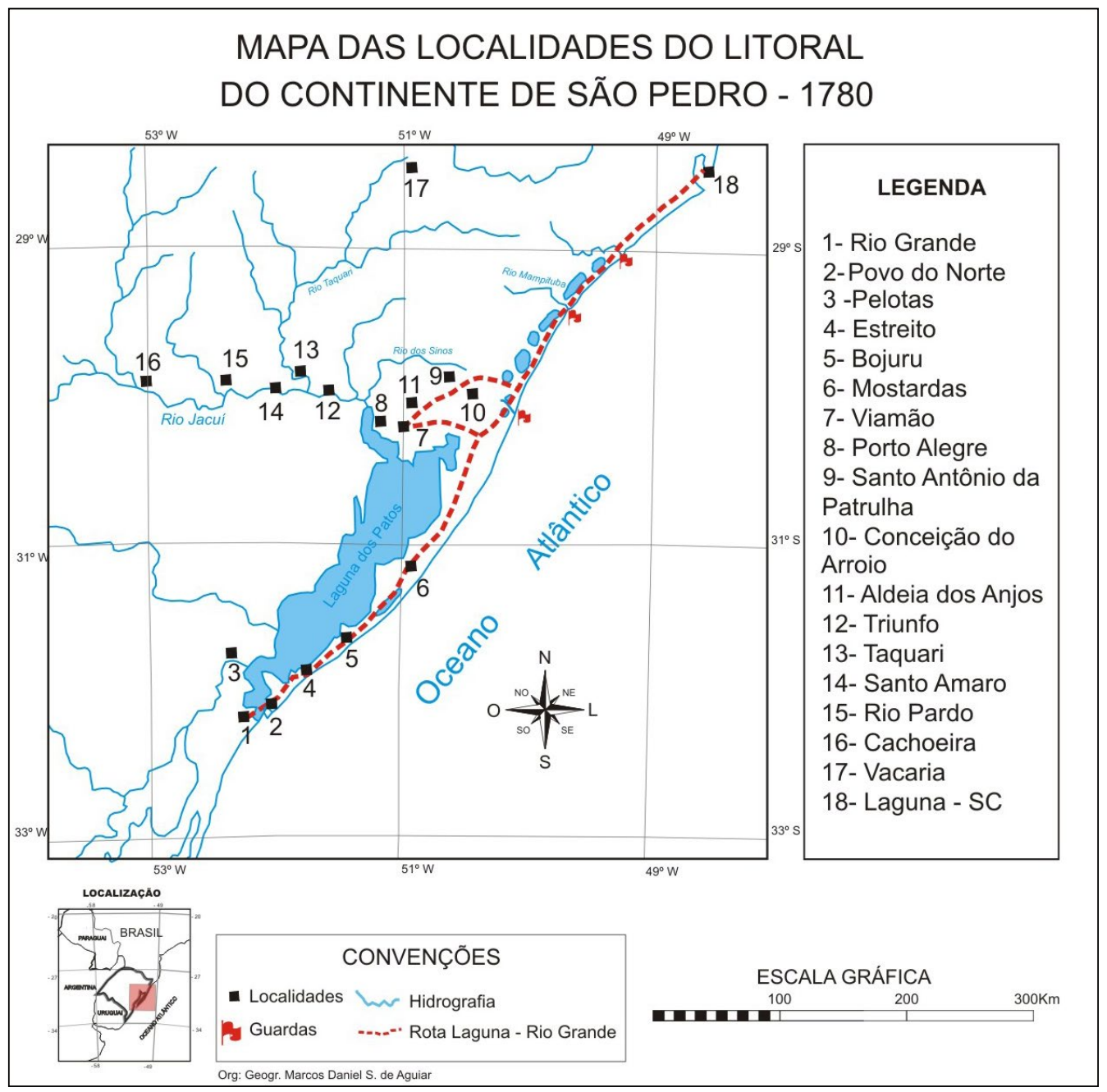

Fonte: Aguiar (2007).

O transporte dos açorianos foi contratado pelo alemão Felix Von Oldemberg, que não se responsabilizava por imprevistos que viessem a ocorrer durante a viagem. O número de imigrantes solicitados pelo Brigadeiro Silva Paes foi de 4000 pessoas (MORAES, 2007). Em relação ao Forte ou presídio Jesus-Maria-José, consta que:

A criação deste presídio evidenciou a importância das terras do Sul. Era difícil povoar estas pastagens. Foi então que a Coroa se lembrou dos Açores. Em 1747, açorianos solicitaram ao Rei que lhes permitisse imigrar para o Brasil, pois a superpopulação do Arquipélago, aliada à má distribuição de terras em poder dos "Morgados", detentores 
dos grandes latifúndios, impedia os minifúndios. A escassez de colheita fazia com que a miséria batesse em todas as portas (ROCHA, 2007, p. 124).

Os anos iniciais da presença açoriana no Rio Grande de São Pedro foram marcados por intensas dificuldades. As autoridades coloniais estavam envolvidas em demandas geradas pela demarcação do Tratado de Madri e pela constante ameaça representada pelos espanhóis. Sendo assim, os contingentes de açorianos que chegavam pelo porto da Vila de Rio Grande não recebiam condições de acomodação satisfatórias, nem a prometida distribuição de terras, nem instrumentos de trabalho e sementes para o plantio. $O$ início da vivência açoriana no Rio Grande de São Pedro foi instável e provisório. Em virtude dessa instabilidade, os açorianos inventaram e reinventaram, no cotidiano, arranjos familiares e relações interpessoais, conforme segue:

Ao chegarem ao Rio Grande de São Pedro, as promessas que lhes haviam sido feitas não foram imediatamente cumpridas. Os casais açorianos e agregados tiveram de esperar, na maioria dos casos, em torno de vinte e cinco anos para conseguir a tão almejada data de terras. Destinados a trabalhar o solo, tiveram de exercer outras atividades e improvisar estratégias de sobrevivência, construindo, nesse processo, laços de solidariedade que lhes permitiram viver em regiões antes desconhecidas, enfrentando carências e dificuldades (GRAEBIN, 2004, p. 178).

Clifford Geertz (1989, p. 15) define cultura como sendo uma teia de significados em que "o homem é um animal amarrado a teias de significados que ele mesmo teceu, assume a cultura como sendo essas teias [...]". Sendo assim, é possível pensar que muitos elementos culturais trazidos pelos açorianos, em contato com a realidade rio-grandense, foram reinventados para suportar as péssimas condições a que foram submetidos no Rio Grande do Sul.

A Região do Vale do Taquari ${ }^{4}$, que atualmente se localiza na porção centro-leste do Rio Grande do Sul, foi tradicionalmente ocupada por grupos indígenas. O povoamento efetivo no Rio Grande do Sul, principalmente na Região Vale do Taquari, ocorreu a partir do momento em que grupos da

4 A designação Região Vale do Taquari politicamente corresponde a uma unidade geográfica dos atuais 28 Conselhos Regionais de Desenvolvimento - COREDEs - criados pela Lei $n^{\circ} 10.283$, de 17 de outubro de 1994 do estado do Rio Grande do Sul. Atualmente abriga 36 municípios: Anta Gorda, Arroio do Meio, Arvorezinha, Bom Retiro do Sul, Canudos do Vale, Capitão, Colinas, Coqueiro Baixo, Cruzeiro do Sul, Dois Lajeados, Doutor Ricardo, Encantado, Estrela, Fazenda Vila Nova, Forquetinha, Ilópolis, Imigrante, Lajeado, Marques de Souza, Muçum, Nova Bréscia, Paverama, Poço das Antas, Pouso Novo, Progresso, Putinga, Relvado, Roca Sales, Santa Clara do Sul, Sério, Tabaí, Taquari, Teutônia, Travesseiro, Vespasiano Correa, Westfália. 
Tradição Ceramista Tupi-Guarani iniciaram sua expansão do Amazonas para o Paraguai, o Uruguai, o norte da Argentina e para diversas regiões do Brasil, o que justifica, durante o século XVIII, a significativa presença Guarani no Rio Grande do Sul (KREUTZ, 2008). Em relação ao povoamento das terras que atualmente constituem a Região Vale do Taquari, temos:

A formação de pequenas povoaç̃oes garantiria, entre várias outras coisas, o adensamento populacional de um vazio demográfico, porque as primeiras doações de sesmarias próximas ao Rio Jacuí não resolveram o problema. Nesse sentido, foram fundados os povoados de São José de Taquari e de Santo Amaro. Estes receberam casais açorianos na década de 1760, havendo 60 deles no vale em 1770. Eram oriundos das primeiras colônias açorianas das margens da Lagoa dos Patos, que migraram para regiões mais propícias ao desenvolvimento da agricultura, pois a fertilidade das terras daquelas povoações atraíram os mesmos. Estes receberam uma data de terras de 272 hectares. Tal foi a preocupação com o povoamento desta região, que, em 1774, houve novos pedidos de casais para a mesma. Os registros de batismo mostram um rápido aumento populacional em função do grande número de filhos dos imigrantes açorianos (CHRISTILINO, 2004, p. 24).

Os primeiros casais açorianos instalaram-se provisoriamente em Taquari, em 1760, sob a orientação do então comandante na capitania, Coronel Inácio Eloi de Madureira. A fundação de Taquari, em 1764, deu-se com a instalação de mais 14 casais. Por ocasião da concessão efetiva das datas, ocorrida em 1770, já se encontravam no local mais de 60 famílias açorianas. Cabe ressaltar que os açorianos instalados no território dedicavam-se ao cultivo do trigo, como uma alternativa para obter o seu sustento (CARVALHO, 2002).

O território que constitui o município de Paverama foi ocupado, primeiramente, pelos indígenas pertencentes à Tradição Tupi-Guarani. Esses Guarani habitaram, inicialmente, nas margens do Rio Taquari, mais precisamente na localidade de Morro Bonito, onde deixaram inscrições em várias grutas, bem como, utensílios de sua cultura material. Segundo Jung (2001), os Guarani permaneceram no local por muito tempo. Quando os colonos açorianos chegaram, fizeram várias incursões contra os recém-chegados. Depois, afastaram-se do local, não mais retornando.

\section{A CULTURA AÇORIANA RETRATADA ATRAVÉS DA GASTRONOMIA E DA ARQUITETURA}

A cultura adquire significados diferentes e marcantes, dependendo da sociedade na qual está inserida. Tanto na sociedade brasileira, quanto na sulrio-grandense, ocorreu uma diversidade de elementos culturais, provenientes de várias etnias, tais como: Charrua, Minuano, Guarani, Kaingang e africanos. 
Em relação aos europeus, os açorianos foram o primeiro grupo étnico a efetivamente colonizar o Rio grande do Sul, como também, muitos deles, a Região do Vale do Taquari. Posteriormente, chegaram os alemães, italianos, poloneses, entre outros, que participaram da formação da sociedade riograndense. Os açorianos trouxeram vários elementos culturais das Ilhas dos Açores, entre os quais apontam-se traços da culinária presentes na gastronomia, aspectos arquitetônicos que influenciaram as suas moradias e a religiosidade, que foi, sem dúvida, o aspecto cultural mais marcante trazido para o Brasil e para o Rio Grande do Sul.

A cultura brasileira, conforme já referimos, formou-se de elementos culturais legados de grupos étnicos vindos de muitos lugares, tais como, de povos originários do continente europeu e africano e de variados grupos indígenas, que habitavam a América do Sul. Nesse sentido, segundo Barth (1998), é possível observar que muitas das fronteiras culturais dos grupos indígenas, africanos, açorianos, alemães, italianos, poloneses, entre outros se mantêm e, portanto, podem ser estudadas como elementos da tradição. Entre esses elementos, salientamos que a formação cultural rio-grandense contou com significativa contribuição de elementos culturais açorianos, já que uma parcela representativa desses colonizadores estiveram presentes em diferentes regiões do Rio Grande do Sul, como, por exemplo, em Porto dos Casais, em Campos de Viamão, em Santo Antônio da Patrulha, etc, mas, também, nos vales como é o caso do Vale do Rio Pardo e do Vale do Rio Taquari. Em relação à cultura, um estudioso da temática destaca:

Cultura é uma dimensão do processo social, da vida de uma sociedade. Não diz respeito apenas a um conjunto de práticas e concepções, como, por exemplo, se poderia falar de religião. Não se pode dizer que cultura seja algo independente da vida social, algo que nada tenha a ver com a realidade onde existe [...] cultura diz respeito a todos os aspectos da vida social, e não se pode dizer que ela exista em alguns contextos e não em outros (SANTOS, 1983, p. $44)$.

Desde que os açorianos chegaram em Santa Catarina e no Rio Grande do Sul, trouxeram uma significativa bagagem cultural, que incluía não só variedades gastronômicas, mas, também, elementos religiosos e estilos arquitetônicos, como é o caso do barroco colonial português.

\subsection{A alimentação vista como elemento cultural}

$\mathrm{Na}$ culinária, vários pratos típicos açorianos estão presentes na alimentação diária de muitas pessoas descendentes ou não de açorianos, conforme é possível identificar em narrativas colhidas nas cidades de Taquari e de Paverama. Entre estes pratos açorianos, temos o caldo verde, o fervido, composto por uma mistura variada de legumes e verduras, que, às vezes, é 
complementado com peixes, ou com carne bovina ou porco; quando servido, é acompanhado do pão de trigo sovado, outro prato açoriano considerado um complemento indispensável. Há registros de que, nos Açores, utilizavam o peixe como alimento indispensável; por isso, era usado no caldo verde, mas, quando chegaram ao Rio Grande do Sul, na categoria de colonizadores, precisavam pescá-lo no rio; e, na falta de peixe, passaram a utilizar a carne para complementar o fervido ou o caldo verde.

O peixe, o pescado de uma forma geral, era um alimento que necessitava de certa experiência de pescador, o que também os colonizadores açorianos legaram aos brasileiros. Segundo Moraes (2007, p.143), "habituados a pescar do alto dos penhascos sobre os rochedos, souberam explorar muito bem a costa marítima catarinense e rio-grandense, que não possui nenhum obstáculo [...] tanto no mar quanto nas lagoas e rios [...]".

Segundo Cascudo (2004), a influência portuguesa na alimentação brasileira está presente em nomes relacionados à gastronomia, à fauna terrestre, marítima, fluvial e lacustre. Enfatiza, ainda, que a flora também é amplamente utilizada em utensílios de cozinha, nas provisões (farinha, milho, feijão, arroz), nas técnicas (assado, cozido, guisado, refogado, grelhado, pilado). Além disso, a maioria dos alimentos necessita quase que exclusivamente do acompanhamento de condimentos vegetais.

Em relação à gastronomia açoriana, o entrevistado EA (2009) enfatiza:

[...] lembro com saudades das coisas gostosas que minha mãe e minha vó preparavam [...] as roscas, tradicionais roscas, as roscas até hoje porque agente adora roscas, o meu marido adora rosca, quando era mais novo era chamada de rosqueiro. Então as roscas feitas com polvilho também extraído de mandioca, e cozido em forno de barro, aqueles fornos de rua, que hoje também não existem mais, hoje é o forno elétrico. A canjica feita com milho quebrado, cozido no leite. O bolinho de bacalhau, que era feito somente na sexta feira santa e era muito gostoso, hoje não se faz mais, porque raramente alguma família ainda faz, o bacalhau é muito caro, mas era muito gostoso. A ambrosia feita com ovos, leite e açúcar, um doce delicioso. $\mathrm{O}$ arroz de leite, era o arroz cozido no leite, com açúcar, ficava bem cremoso, era colocado em tigelas e por cima canela moída e a gente se lambuzava toda comendo [...] (EA, 2009, p.6).

Conforme o entrevistado EA (2009), muitos alimentos de origem açoriana ainda hoje estão presentes na mesa, ou seja, parte do alimento que ingerimos todos os dias nos remete a essa etnia, mas muitas pessoas não sabem ou desconhecem esse fato. Ainda, segundo o entrevistado EA (2009), ele guardou vivas na memória e hoje põe em prática as receitas ensinadas por sua avó e sua mãe. Estas narrativas são obtidas das entrevistas com base na metodologia da história oral, assim definida por Alberti (2004): 
[...] entrevista de história oral são fontes que documentam o passado - experiências pessoais, acontecimentos, conjunturas - e as concepções sobre passado através de sequências narrativas, isto é, pequenas histórias cujo sentido está atrelado à forma com que são narradas, sendo impossível dar conta do primeiro (o sentido) sem considerar a segunda (forma) (ALBERTI, 2004, p. 73).

As pessoas constroem sua identidade a partir de fatos relevantes, de raízes do passado, que foram culturalmente construídas ao longo dos anos. A ancestralidade diz muito sobre o presente de cada pessoa; por isso, a importância de observarmos a identidade cultural considerando os ensinamentos dos antepassados.

Os doces de leite e em calda feitos de frutas diversas eram bastante apreciados pelos colonizadores açorianos, sendo uma prática diária adotada em sua gastronomia. Alguns autores como Santos (2007), Moraes (2007), Ramirez (2005), entrevistados EA (2009) e ER (2009) confirmam o uso dos doces em larga escala na alimentação dos colonos açorianos. A tradição de servir doces, principalmente, às visitas ainda está presente nas cidades de Paverama e Taquari, bem como, nas cidades do litoral gaúcho, como Osório, Santo Antônio da Patrulha e Tramandaí. No município de Paverama, prevalece, na sobremesa diária, o arroz-doce ou arroz de leite e os doces em calda, também chamados de compotas de frutas, a ambrosia, entre outros.

Segundo Barroso (2008), alguns pratos do cotidiano rio-grandense reafirmam a herança lusa (dos continentais e ilhéus), como os cozidos e fervidos. A açorda ainda preservada é apreciada por muitos que repassam às novas gerações o gosto por este prato. A doçaria é riquíssima, preparada de várias formas, que resultam em apreciadas guloseimas, disputadas nos cafés. Para exemplificar a lista, apontamos: pão de ló, arroz-doce, ovos moles, suspiros, rosquetes e rosquinhas, sonhos, doces com frutas, etc, além de pães variados, sovados e batidos, em formatos diversos.

Segundo Victor Américo Cabral, temos:

[...] os açorianos dependendo do espaço geográfico em que se estabeleciam, plantavam trigo, abóbora, feijão, couve, cebola, mandioca, batata, milho, nabos, melancias, cana-de-açúcar, cevada, alpiste, aveia, ervilha, centeio; no pomar, cultivavam árvores de espinhos (laranjeiras, limoeiros, bergamoteiras, pessegueiros, bananeiras, amoreiras, pereiras); também cultivavam vinhas, cochonilha, cânhamo e erva-mate (CABRAL apud GRAEBIN, 2006, p. 217).

No Rio Grande do Sul, recorreram a várias tradições culinárias trazidas dos Açores e complementaram e/ou substituíram os alimentos que encontraram. Com o passar do tempo, a tradição culinária açoriana passou a 
ser incorporada aos hábitos alimentares das famílias descendentes ou não de açorianos. No entender de Santos (1994, p. 44-45), a cultura deve ser entendida como "uma construção histórica [...]; é uma dimensão do processo social, da vida de uma sociedade [...]; cultura diz respeito a todos os aspectos da vida social".

Sendo assim, pode-se afirmar que a tradição cultural é uma construção histórica, que é capaz de permanecer presente na vida das pessoas que a compõem. Portanto, os elementos culturais do grupo étnico em questão, como, por exemplo, a gastronomia, podem ser tomados como indicadores da continuidade cultural açoriana, presente na degustação das pessoas que compõem as comunidades em Taquari e Paverama.

\subsection{A arquitetura como demonstração da cultura açoriana}

Nas cidades de colonização açoriana, foi empregada uma arquitetura simples e modesta, tanto nas primeiras residências como nas igrejas. $\mathrm{O}$ estilo arquitetônico empregado foi o colonial barroco. Nas localidades dos municípios de Taquari e Paverama, pesquisadas para este estudo, não existe nenhuma residência propriamente construída por colonizadores açorianos; permanece somente o estilo arquitetônico em algumas residências, empregado pelas gerações que sucederam os primeiros colonos (figura 2).

Figura 2: Vista Parcial da Casa do Artesão em Taquari - Rio Grande do Sul

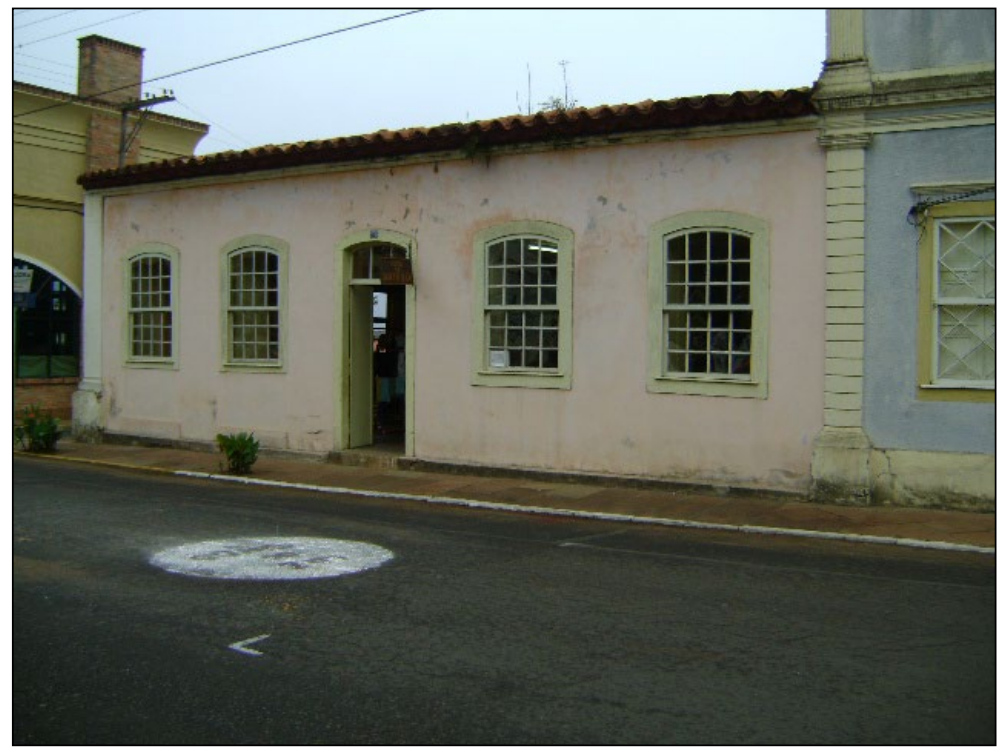

Fonte: Dos autores. 
Em Taquari, somente a Igreja São José é contemporânea, erguida pelos primeiros colonizadores açorianos. Porém, no decorrer dos anos, sofreu influência e modificações em sua estrutura. Já em Paverama, não há nenhuma residência típica açoriana, ainda que o município da Região do Vale do Taquari na época pertencesse a Taquari, onde as residências foram construídas e permanecem até hoje. Em Paverama, existe somente uma igreja de estilo colonial barroco; trata-se da primeira igreja construída, cuja influência no estilo remete aos primeiros colonizadores açorianos. Taquari é um dos únicos lugares na Região Vale do Taquari que mantém uma arquitetura colonial barroca, que remete à cultura açoriana.

Acerca das primeiras residências construídas por açorianos, a depoente ER aponta:

[...] A localização desse assentamento urbano dos primeiros açorianos, dos fundadores da cidade de Taquari foi no que nós vamos à praia hoje, o bairro Praia, que é uma localidade às margens do Taquari. Então na primeira enchente grande que teve, levou essas casinhas deles, que já eram pobrinhas. Era daquelas taquaras e galhos e troncos de árvores. Então a primeira enchente grande que teve levou. E por que eles aceitam essa localização? Essa fixação bem nas barrancas do rio? Porque eles são das ilhas dos Açores, onde não há em nenhuma dessas ilhas, não há rios. Lá tem ribeiras. Então não há rios, eles não conheciam o que é uma enchente, o que seriam as cheias. Então a primeira enchente que deu, levou tudo. Eles se apavoraram. O pouco que tinha que não era quase nada a enchente levou [...] (ER, 2009, p. 9).

Santos (2007) afirma que os primeiros açorianos que fundaram São José de Tebiquary enfrentaram dificuldades econômicas, o que não poderia ser esquecido. O resultado era visível na arquitetura muito simples e pobre, que refletia a situação de carência em que viviam. De acordo com Macedo (1984), a casa rural açoriana é limitada por paredes, geralmente, de madeira, ficando de um lado a cozinha e do outro, o quarto e as camas. A cozinha, semelhante à da casa urbana, com forno, lar, trempe e chaminé, era estreita, mas com toda a largura do fogão. O chão era de terra batida e o forno, esférico. Ainda, segundo o referido autor, na área urbana, esta planta se altera. Nesse sentido, ele destaca:

[...] A cozinha, com seu "lar" e forno, sua "copeira" e "trempe" deixou de ter posição em linha com as outras duas peças e foi deslocada para trás, nela se farão as reuniões e os trabalhos domésticos diurnos. As outras duas peças se tornaram área de recolhimento [...] Maiores comodidades são reveladas pelos armários embutidos semelhantes às copeiras. A falsa, dormitório no telhado, continua com acesso sobre o quarto maior. E, finalmente, se verifica que na casa urbana ou na residência encravada, os quartos são defendidos das áreas de circulação diurna pela presença do corredor. Verifica- 
se em muitas destas casas modestas, que apenas um dos quartos dispõe de assoalho e nele, além da cama há quadros com fotografias pelas paredes e uma mesa com toalha alvíssima para receber os objetos mais preciosos da família: vasos, lampiões, caixas de joias, estatuetas e santinhos de várias cores e tamanhos (MACEDO, 1983, p.69).

Segundo o entrevistado ER (2009), os açorianos que colonizaram Taquari fizeram as suas casas com o que eles tiravam do mato, da barranca do rio. Provavelmente, eles tiravam os galhos e os troncos de árvores, como, também, taquaras, cipós e barro para fazerem as suas casas de acordo com a planta urbana traçada na época para a cidade, onde tinha a praça, as ruas, a igreja.

Conforme Santos (2007), na cidade de Taquari, à medida que o tempo passava, os recursos econômicos ampliavam-se para alguns, não só melhorando a qualidade de vida, mas, também, as construções dos prédios. A partir daí, passa a predominar uma arquitetura de forma retangular, geralmente, com mais de uma entrada e janelas colocadas simetricamente.

A Igreja Matriz São José, atualmente situada no centro da cidade de Taquari, é contemporânea dos primeiros açorianos que a colonizaram. Sobre o estilo arquitetônico da Igreja São José, a entrevistada ER (2009) faz o seguinte comentário:

[...] Ela leva o nome de São José em homenagem ao rei de Portugal que era na época Dom José. Então se achou por bem e em homenagem ao rei de Portugal colocar o nome da Igreja, como o nome do povoado de São José de Tebiquary, padroeiro então sendo São José. A construção da nossa Igreja Matriz então é simples, também a forma é colonial, as paredes são grossas, as pedras da construção são retiradas aqui do local, mantém - se o estilo português no templo, que é um altar principal, ladeado de dois menores. Então se tu entra na nossa Igreja tu vai ter o altar - mor, o altar principal, de cada lado um altar menor. A construção é simples, mas ela é muito bonita, talvez mesmo por essa sua simplicidade. O teto é em forma de abóbada, mantendo sempre esse mesmo modelo, esse mesmo padrão. E é isso que eu tenho a dizer sobre a Igreja. Não, eu esqueci de uma coisa importante, que essa Igreja então, que recebe como padroeiro São José em homenagem ao rei de Portugal, que era Dom José, ela recebe do rei Dom José, uma imagem de São José e madeira. Essa imagem de São José em madeira, vinda de Portugal ainda se encontra na Igreja. É claro que hoje ela está guardada como uma relíquia e tem uma cópia no lugar, mas a imagem verdadeira, a primeira, ela ainda existe, e só tá chaveada, sai nas procissões, uma vez por ano na festa de São José ou em um evento que precise, mais de mais a mais o restante do tempo fica chaveada, guardada (ER, 2009, p.11). 
Já no município de Paverama, conforme já mencionamos, não existe nenhuma residência com o estilo arquitetônico herdado dos açorianos, porque, na época da colonização, este município pertencia ao município mãe, Taquari. Somente a partir de 1855-1860, os primeiros colonizadores açorianos estabeleceram-se no atual território pertencente à Paverama. Provavelmente, pelo fato de a construção das primeiras moradias ser simples, elas não resistiram ao tempo. As casas mais antigas localizadas hoje na cidade de Paverama são todas de influência alemã, já que os colonizadores alemães sucederam os açorianos na colonização do solo paveramense. Remetendo à cultura açoriana, existe uma igreja no interior do município, na localidade de Santa Manoela, cujo nome é Capela São José (fig 3), construída no início do século XIX. Na construção desta igreja, foi utilizado o estilo arquitetônico barroco. Esta igreja também tem como santo padroeiro, São José. Assim, é semelhante à Igreja de Taquari, pois tem o mesmo design, nome e comemoração anual, que ocorre em 19 de março.

Figura 3: Vista Parcial da Capela São José em Paverama - Rio Grande do Sul.

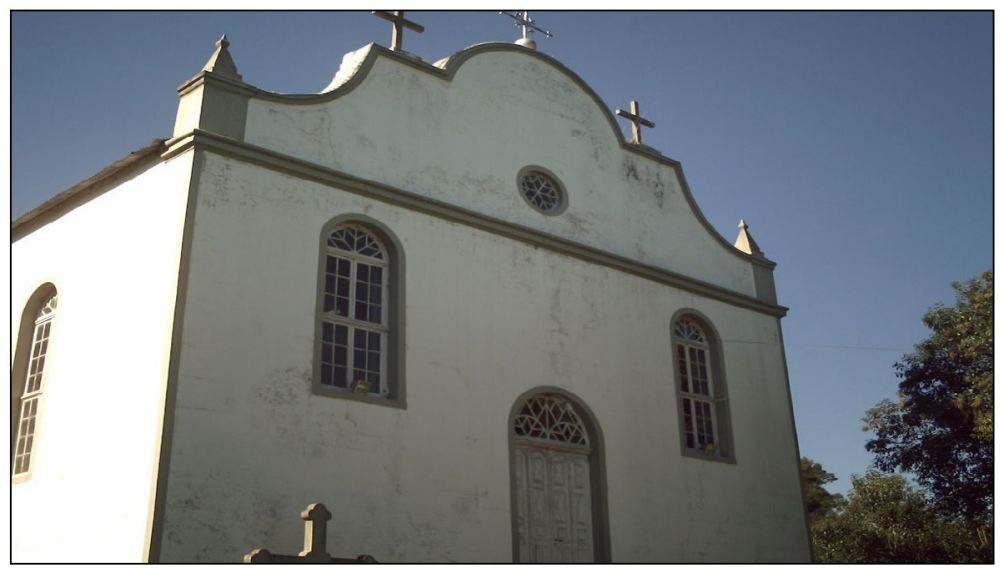

Fonte: Dos autores.

\section{A CULTURA AÇORIANA OBSERVADA ATRAVÉS DA RELIGIOSIDADE}

Desde o início da colonização açoriana no Rio grande do Sul, a igreja era considerada o centro do povoamento e dos núcleos urbanos que se formavam. Os povoados eram construídos, na maioria das vezes, ao redor de uma capela ou de uma igreja. A construção de capelas e igrejas mobilizava a participação coletiva, com doação de material e trabalho voluntário. A religiosidade era cultivada nas famílias. A oração fazia parte da rotina diária, principalmente, a reza do terço, quando as famílias se reuniam para reverenciar a Deus. 
Os colonizadores açorianos, conforme já foi comentado, trouxeram vários elementos culturais das Ilhas dos Açores, sendo a religiosidade o mais preponderante. $\mathrm{O}$ ambiente insular banhado pelo Oceano Atlântico e atingido pelas intempéries climáticas, tais como, terremotos e erupções vulcânicas, por exemplo, possivelmente necessitava de proteção divina, que resultou na religiosidade desses colonizadores.

Em se tratando da Região Vale do Taquari, as diferenças econômicas e sociais marcadas pela posse e pelos status existiam, mas, conforme Santos (2007), independente destas condições, a Igreja ditava normas e toda a população costumava segui-las. Ressalta-se que os açorianos, no início da colonização, eram todos católicos.

Conforme Mircea Eliade (2010), de acordo com a concepção religiosa, a noção de espaço não é homogênea, pois o templum simboliza a síntese do espaço sagrado. No contexto brasileiro e também no dos açorianos, a igreja colonial, bem como, suas festividades, simbolicamente, ilustram o espaço sagrado em oposição ao mundo profano. De acordo com Centurião,

[...] manifestando-se esse fato claramente tendo no comportamento das pessoas, como nas próprias finalidades às quais era destinado o espaço do templo. Local privilegiado para encontros amorosos, acertos de negócios, barulhentas conversas sobre os mais variados assuntos mundanos, mercado de amuletos, antro de embustes religiosos, palco de danças e exibição ostentatória, valhacouto de frades priápicos, nada mais distante deste espetáculo social que tem a igreja como palco, desse comportamento exuberante e tropical, ao mesmo tempo cristão e pagão, lusitano, asiático e africano do que a austera religiosidade [...] (CENTURIÃO, 1999, p. 291).

Na concepção do entrevistado ER (2009, p.5), ainda em relação à religiosidade, o caráter sagrado das festas religiosas também fica evidenciado, sendo a comemoração das festas religiosas, uma grande herança mantida tanto no interior quanto na cidade. Sem perder a fé, sem perder o espírito religioso, é associada a uma festa que se caracteriza como profana, pois ocorre com festejos, folguedos, comes, bebidas, cantares, etc.

Conforme já mencionado, é possível perceber que, através da gastronomia, da arquitetura e da religião, muitos elementos culturais açorianos foram preservados ou reatualizados. A religião, em particular, constituise num dos principais centros de irradiação de valores morais, de disciplina e de solidariedade da comunidade. A fé fez surgir capelas e capelinhas, cuja imagem, como é o caso de Nossa Senhora de Fátima (Figura 4), passava de casa em casa para congregar as famílias num momento de devoção. Também havia os grupos de oração e as irmandades, também elementos marcantes dos colonizadores açorianos. 
Figura 4: Capelinha com a imagem de Nossa Senhora de Fátima, em Paverama, Rio Grande do Sul.

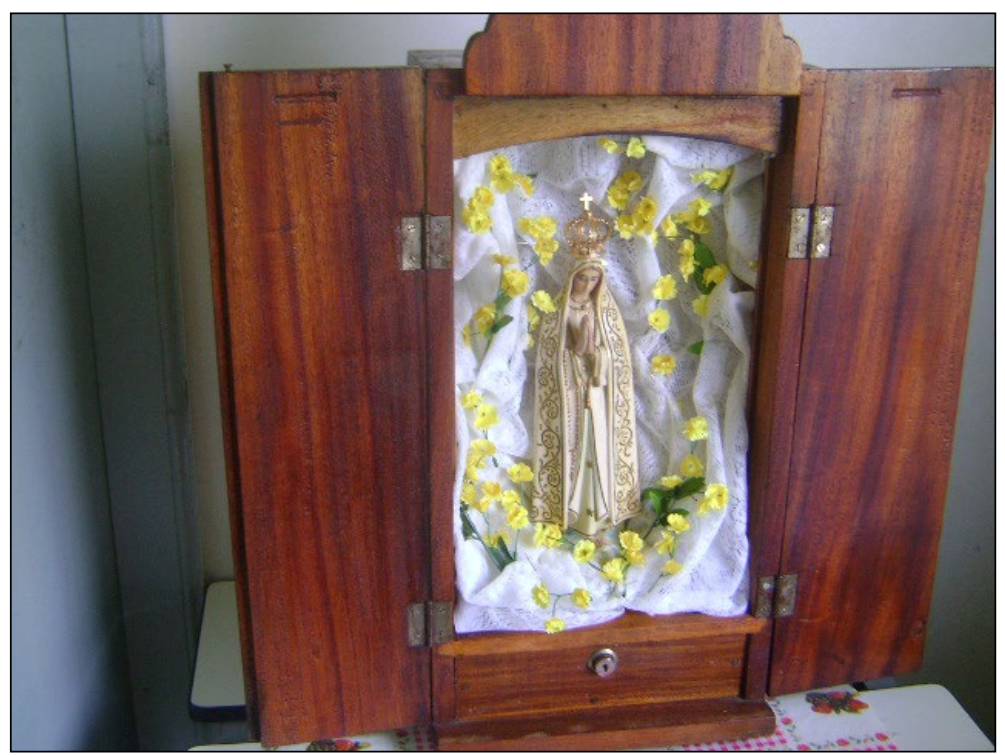

Fonte: Dos autores.

\section{1 A religiosidade açoriana retratada através das Irmandades religiosas}

Conforme Graebin (2004), as Irmandades religiosas têm sua origem no Rio Grande do Sul, com a chegada dos primeiros colonizadores açorianos, que mantinham essa prática religiosa na Ilha dos Açores. Seus princípios são regidos por aspectos lusos, pois foi Portugal, continente, que povoou a Ilha dos Açores, que deu origem às Irmandades, que, no século XVIII, foram trazidas pelos colonizadores açorianos para Santa Catarina e para o Rio Grande do Sul.

Segundo Santos (2007) e o ER (2009), mais precisamente na cidade de Taquari, as Irmandades religiosas serviram como elo entre o catolicismo e a população, bem como, meio de sociabilidade na comunidade, a qual elegia um santo de devoção para solicitar sua proteção. As Irmandades religiosas são associações fraternais, ou seja, os membros que a compõem são, também, denominados de "irmãos".

Historicamente, segundo Tavares (2008), as irmandades, que têm origem na Idade Média, recorriam à adoração e à procissão aos santos, segundo os ofícios, suplicando-lhes proteção, como, por exemplo, no caso da Peste Negra. Também, segundo Natalie Davis, "as Irmandades no século XVI na Europa auxiliavam os pobres com doações de comida, dinheiro e roupas, o que era uma continuidade da Idade Média, às vezes praticavam ajudas funerais, hospitais e socorro das confrarias a seus membros pobres em tempos difíceis [...] Elas 
socorriam os pobres piedosos, respeitáveis, não criminosos ou prostitutas" (DAVIS apud TAVARES, 2008, p.114).

Segundo o entrevistado EG (2009, p.1), a Irmandade São José de Taquari "foi criada primeiro para dar assistência aos pobres. Era um sistema que veio das Ilhas de Açores. Era um grupo que se encarregava de fazer o enterro das pessoas pobres e também como grupo de oração".

Ainda, em relação ao objetivo da irmandade São José, o entrevistado EG afirma:

[...] Não. O enterro dos pobres, isso não existe mais. Ainda na reunião de sábado, a última reunião foi agora sábado, nós estamos tentando reformular os estatutos. Eu como sou um conhecedor da história e escritor fui encarregado inclusive de fazer um histórico de toda a Irmandade, dos fatos relevantes, interessantes, registrados em Ata pra ver o que realmente aconteceu (EG, 2009, p.2).

De acordo com Balém (1956), Santos (2007), Tavares (2008), entrevistas EG (2009), ER (2009), e EW (2009), as irmandades, que tinham um santo de devoção específico, estavam bastante organizadas na cidade de Taquari. Atualmente, a irmandade de São José, a única que permanece, ainda cultua o seu santo de devoção e exerce as atividades que a ela competem (Figura 5).

Ainda em relação à Irmandade São José, bem como, às demais ${ }^{5}$ que se formaram na cidade de Taquari, a depoente ER destaca:

[...] A irmandade de São José, ela era responsável, e é responsável pelas festas de São José. Ela que faz as novenas, que organiza as novenas e as festas em homenagem ao nosso padroeiro. Outra irmandade que também teve grande importância foi a irmandade do Divino Espírito Santo que se dedicava as festas religiosas também, faziam lá as suas homenagens ao Espírito Santo. Na festa então se fazia os agradecimentos às graças alcançadas, se fazia pedidos para o próximo ano esse fazia todo um cortejo nas ruas em procissão em homenagem ao Divino Espírito Santo. Essa irmandade também não existe aqui na nossa terra, mas a irmandade do Divino Espírito Santo por muitos outros lugares do Rio Grande do Sul se mantém forte fazendo suas festas. Depois outra irmandade que havia era então a irmandade de São Miguel, que essa irmandade se preocupava, se empenhava como o sufrágio das almas, então se rezava pelas almas, porque se diz que depois da morte alma está indo para algum lugar, então vamos rezar para salvar a alma, a alma pelos falecidos. E tinha também a irmandade do Rosário e de São

5 No início da colonização açoriana na cidade de Taquari existiam vários grupos de irmandades, dentre as quais podemos apontar: Irmandade do Divino Espírito Santo, Irmandade do Santíssimo Sacramento, Irmandade do Rosário e de São Benedito (ER, 2009). 
Benedito, que eram as irmandades compostas por pessoas negras, porque nós estamos ainda nesse período, no auge da escravatura. Então os negros não se misturavam, mas como eles mantinham a fé católica, se converteram, eles mantinham também a sua tradição religiosa, como estavam aqui, se infiltraram nesta cultura açoriana e formaram também as suas irmandades, só que não podiam ser misturadas por pessoas negras [...] (ER, 2009, p.12).

Figura 5: Membros da Irmandade São José em Taquari, Rio Grande do Sul

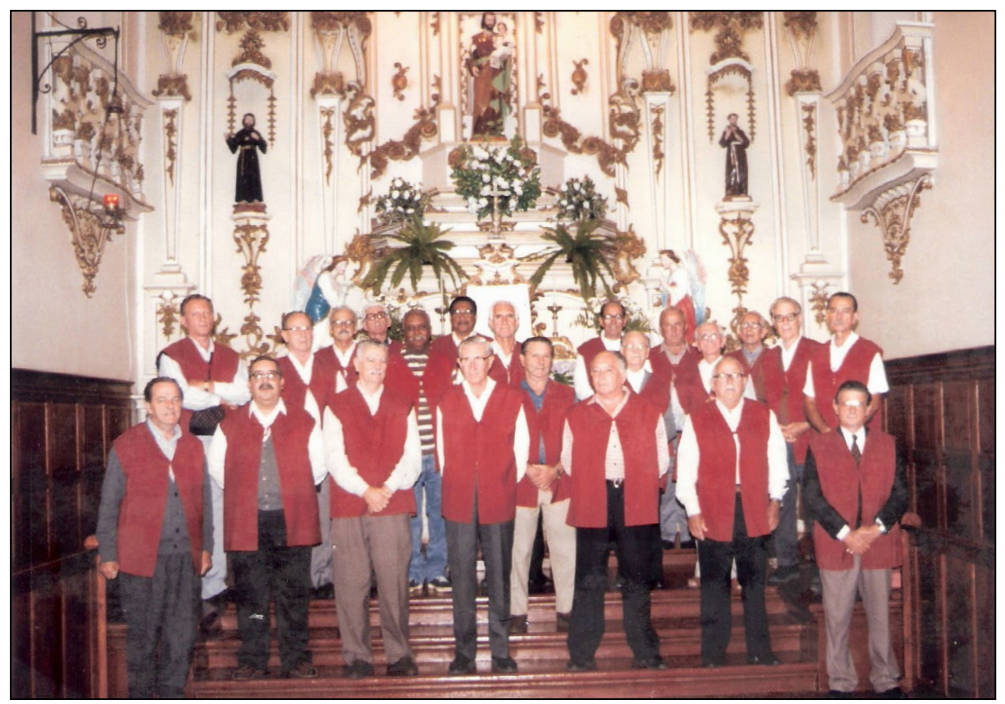

Fonte: Acervo particular da família Goerckt (1998).

As referidas irmandades eram uma forma de retratar a religiosidade do povo açoriano nas procissões ou nas demais atividades exercidas pelo grupo, que se reunia para rezar e para conversar. Em relação às Irmandades, Tavares (2008, p. 117) destaca que foi "este caráter medieval do catolicismo, de fé e de adoração das imagens santas e da crença no poder dos santos, que acompanhou a colonização do Brasil e se estendeu ao século XIX. Instaladas no Brasil colonial, as irmandades seguiam - como modelos de organização interna - os compromissos portugueses, uma herança do período medieval".

A Irmandade São José da cidade de Taquari completou 208 anos. Em reportagem do jornal, O Fato Novo, registra-se que "a Irmandade de São José, cujo livro de atas data de 03 de setembro de 1806, traz à lembrança dados, riquezas que antepassados deixaram. Possui estatuto próprio e, na Ata de 17 de março de 1996, foram aprovados outros estatutos que não alteraram os anteriores" (O Fato Novo, 13 de março de 2009, p. 8).

De acordo com Graebin (2004), é vedada a participação de mulheres nas irmandades. Questionando o entrevistado EG (2009) acerca da participação 
de mulheres na irmandade São José, registrou-se o seguinte depoimento: “[...] quanto às mulheres há novamente um movimento que as mulheres querem participar da Irmandade, criar uma Irmandade, mais não há assim restrições quanto a isso e também não há um grande incentivo ou iniciativa, parte de um grupo pequeno (EG, 2009, p.1).

No entender de Graebin (2004) e Tavares (2008), as irmandades foram criadas no Rio Grande do Sul com o propósito de acabar com os abusos cometidos pelos colonos açorianos nas festas religiosas. Elas seriam uma forma de conter ou de remover os excessos praticados, porque, algumas vezes, essas festas foram consideradas profanas aos olhos da igreja.

Sobre a perpetuação da cultura açoriana através das irmandades religiosas, o entrevistado ER (2009) enfatiza:

[...] Os açorianos trouxeram isto como herança porque essas irmandades já existiam nos Açores, as irmandades não são coisas criadas no Rio Grande do Sul, pode até ser que lá em Portugal e mesmo especificamente nos Açores tivessem essa conotação de cada irmandade querer fazer de forma mais bonita uma homenagem ao seu santo padroeiro até pode. Não fiz um levantamento sobre isto, mas to dizendo que há esta possibilidade, mas aqui no Rio Grande do Sul não houve essa criação aqui, porque isto é um legado cultural e religioso vindo dos Açores [...] (ER, 2009, p. 15).

Ainda acerca da colonização açoriana no Rio Grande do Sul e no Vale do Taquari, pode-se afirmar que, através da construção da capela ou da igreja em lugares distantes, possibilitou-se a comunicação entre os primeiros colonos açorianos, a sociabilidade entre as comunidades, bem como, a preservação de muitos elementos culturais e religiosos, repassados aos filhos, aos netos e aos demais descendentes. Além disso, eram construídos laços de amizades significativos entre os açorianos, o que possibilitava o auxílio mútuo no trabalho, tanto para moer mandioca nas atafonas, como na matança de porcos.

Com as narrativas obtidas através de entrevistas, é possível retomar fatos, histórias e relatos relevantes como fontes orais da história açoriana, conforme ilustra Lang (1996):

[...] História Oral seria um termo amplo, que recobre tipos variados de relatos obtidos através de fontes orais, a respeito de fatos não registrados por outro tipo de documentos, de fatos cuja documentação se quer completar, ou que se quer abordar por ângulo diverso. A história oral registra a experiência vivida ou o depoimento de um indivíduo ou de vários indivíduos de uma mesma coletividade (LANG, 1996, p. 34).

Ainda, relativo às festividades religiosas, atualmente, a mais popular da cidade de Taquari é a festa de São José, conforme segue: 
[...] a festa mais popular é de fato a de São José, a novena de São José, e o dia de São José é até feriado municipal, e então o povo todo toma muito conhecimento desta festa, participa, uns mais outros menos, porque tem como eu disse a novena, 9 noites com celebração na Igreja matriz, procissão no dia, quase cada noite um jantar, então ela de fato meche com muita gente de Taquari. Outras festas populares, mas é claro são as da Semana Santa, de Corpus Christi, e têm mais festas religiosas sem maior influência nos que não se ligam à religião. Enquanto a Festa de São José, também atinge muitos que não vêm pra igreja, mas vêm para os jantares, vêm participar da festa mais externa. Então a mais popular eu penso que é a de São José (EW, 2009, p. 4).

Segundo Goerckt (2009), acontece anualmente em Taquari, precisamente em 19 de março, uma significativa comemoração religiosa do município, a Festa de São José, cujo início retrocede à década de 1930. Esta data culmina com um feriado na cidade e confraternização durante nove dias entre os taquarienses.

[...] Na parte religiosa destacam-se as novenas realizadas todas as noites na Igreja Matriz, através de missas ou bênçãos, com numerosa participação, composta pela Irmandade de São José, casais festeiros, entidades, comunidades convidadas e população em geral. Após, são servidas jantas no Salão Paroquial, variando o cardápio a cada dia e organizadas sempre por diferentes grupos da comunidade (GOERCKT, 2009, p. 203).

Também, em Paverama, existem várias festas religiosas, que, na opinião de EN (2009), também são populares, conforme relato que segue:

Além da festa da padroeira, melhor dito em primeiro lugar a festa de Corpus Christi, que antecede vem antes e a festa da padroeira que vem depois, agora em outubro. Acredito que a festa do natal, além de ser uma das três maiores festas do ano, claro precedido pela páscoa, que é a maior festa litúrgica de toda a igreja. O natal é muito significativo, festa do Santo Natal, Ano Novo, e claro a Páscoa também é bastante celebrada, a Semana Santa. É muito difícil dizer precisamente qual seria a mais importante. Creio que do ponto de vista popular é muito, é bastante, tem um significado bastante importante, mais acredito que também não perde muito pela páscoa (EN, 2009, p. 3).

Em relação às irmandades, retrocedendo ao século XVIII, quando Paverama denominava-se "Arroio Grande" e pertencia à localidade de Taquari, narrativas orais mencionam uma irmandade conhecida como Nossa Senhora do Rosário, destinada a negros. Ressaltamos, entretanto, que não encontramos outros registros ou documentos acerca da Irmandade Nossa senhora do Rosário na referida região. 


\section{CONSIDERAÇÕES FINAIS}

Os açorianos vieram para o Brasil, especificamente para o Rio Grande do Sul, na segunda metade do século XVIII, mais precisamente em 1750, trazendo consigo diversos elementos da tradição. Esses elementos podem ser exemplificados através da gastronomia açoriana com a utilização do peixe, dos fervidos e dos doces de calda, bem como, através da presença da arquitetura de estilo colonial barroco nas casas e nas igrejas. No que tange à religiosidade, a presença de alguns destes elementos da tradição açoriana podem ser observados na constituição das irmandades, na procissão de Corpus Christi, na reza de terço, nas procissões em homenagem aos santos padroeiros e nas visitas da capelinha com a imagem para devoção. Particularmente, na cidade de Taquari, destacam-se, ainda, a encenação do Natal Açoriano, a encenação da Paixão de Cristo e a Romaria ao Santuário de Nossa Senhora da Assunção. Nesse sentido, considerando a cultura como algo dinâmico e tomando o caso açoriano em particular, constatamos que, apesar do processo de colonização e de formação do Estado Nacional Brasileiro, inúmeros elementos da tradição açoriana foram mantidas e/ou reatualizadas pelos colonizadores e por seus descendentes.

\section{REFERÊNCIAS}

ACERVO da Família Goerckt, 1998. Membros da Irmandade São José em Taquari, Rio Grande do Sul. 1 fotografia color, $10 \mathrm{~cm}$ x $15 \mathrm{~cm}$. Foto digitalizada. Formato JPEG.

ALBERTI, V. Ouvir contar: textos em História Oral. Rio de Janeiro: FGV, 2004.

BALÉM, J M. A Igreja Católica no Rio Grande do Sul até 1912: sua evolução geral. In: BECKER, K (Org.). Enciclopédia Rio-Grandense: O Rio Grande Antigo. Canoas: Editora Regional Ltda, 1956. p. 3-21.

BARROSO, V L M. Os açorianos no Rio Grande do Sul. In: BARROSO, V L M; BRITO, G M de (Org.). Arquitetando Santo Amaro a partir de suas raízes. Venâncio Aires: Traço, 2008, p. 129-135.

BARTH, F. Grupos étnicos e suas fronteiras. In: POUTIGNAT P; STREIFF-FENART, J (org.) Teorias da etnicidade. São Paulo: UNESP, 1998. p. 187-227.

CARVALHO, V R. Da ilha dos Açores à freguesia de Taquari: uma trajetória dos imigrantes açorianos no continente do Rio Grande. Estudo e Debate. p. 39-57. n. 9. 2002.

CASCUDO, L C. História da Alimentação no Brasil. São Paulo: Global, 2004.

CENTURIÃO, L R M. A cidade colonial no Brasil. Porto Alegre: EDIPUCRS, 1999. 
CHRITILLINO, C L. Estranhos em seu próprio chão: O processo de apropriação e expropriação de terras na Província de São Pedro do Rio Grande do Sul (O Vale do Taquari no período de 1840-1889). Dissertação de Mestrado em História, Universidade do Vale do Rio dos Sinos, São Leopoldo. 2004.

ELIADE, M. O Sagrado e o Profano; A essência das religiões. 3. ed. São Paulo: Editora WMF, Martins Fontes, 2010.

EA - Entrevista EA: relato [27 mai. 2009]. Paverama/RS. Entrevistador: Cleidirose da Silva. Paverama (RS): s.e. 2009. Gravação em fita mini-cassete. 1 fita de $45 \mathrm{~min}$. Entrevista concedida a Cleidirose da Silva.

EG - Entrevista EG: relato [05 out. 2009]. Taquari/RS. Etnrevistador: Cleidirose da Silva. Taquari (RS): s.e. Gravação em fita mini-cassete. 1 fita de 25 min. Entrevista concedida a Cleidirose da Silva.

EN - Entrevista EN: relato [19 out. 2009]. Paverama/RS. Entrevistador: Cleidirose da Silva. Paverama/RS: s.e. Gravação em fita mini-cassete. 1 fita de 25 min. Entrevista concedida a Cleidirose da Silva.

ER - Entrevista ER: relato [09 mai. 2009]. Taquari/RS. Entrevistador: Cleidirose da Silva. Taquari/RS: s.e. Gravação em fita mini-cassete. 1 fita de $60 \mathrm{~min}$. Entrevista concedida a Cleidirose da Silva.

EW - Entrevista EW: relato [10 out. 2009]. Taquari/RS. Entrevistador: Cleidirose da Silva. Taquari/RS: s.e. Gravação em fita mini-cassete. 1 fita de $60 \mathrm{~min}$. Entrevista concedida a Cleidirose da Silva.

GEERTZ, C. A interpretação das culturas. Rio de Janeiro: Zahar, 1989.

GRAEBIN, C M G. Sonhos, desilusões e formas provisórias de existência: os Açorianos no Rio Grande de São Pedro. Tese Doutorado em História, Universidade do Vale do Rio dos Sinos. São Leopoldo. 2004.

GRAEBIN, C. Vida cotidiana dos açorianos pelas freguesias e caminhos. In: BOEIRA N, GOLIN, T (coord.). História do Rio Grande do Sul. Passo Fundo: Méritos, 2006, p. 203-223.

GOERCKT, B. Taquari após retorno à vida democrática no Brasil em 1947:

Legislação: $1^{\mathrm{a}}$ lei- $1^{\mathrm{o}}$ decreto - fatos relevantes, curiosos e pitorescos. Lajeado: Fortgraf, 2009.

JUNG, F N. Paverama: Fatores de sua Emancipação. Monografia Especialização em História, Universidade de Santa Cruz do Sul, Santa Cruz do Sul. 2001.

KREUTZ, M R. O contexto ambiental e as primeiras ocupações humanas no Vale do Taquari-Rio Grande do Sul. Dissertação Mestrado em Ambiente e Desenvolvimento, Centro Universitário Univates, Lajeado. 2008. 
LANG, A B da S G. História Oral: muitas dúvidas, poucas certezas e uma proposta. In: MEIHY, J C S B (Org.). (Re) introduzindo a História Oral no Brasil. São Paulo: Xamã, 1996. p. 33-47.

MACEDO, F R de. Arquitetura luso-brasileira. In: BERTUSSI, P I et al. A Arquitetura no Rio Grande do Sul. Porto Alegre: Mercado Aberto, 1983, p. 53-94.

MORAES, M J de. Balneário Pinhal: Resgatando suas raízes açorianas e fazendo sua história. In: ROCHA, S. I. D. da (Org.). Açorianos no Rio Grande do Sul-Brasil II. Porto Alegre: ed. Caravela, 2007, p. 122-126.

O FATO NOVO. Procissão em honra a São José será na quinta-feira. In: Jornal O Fato Novo. 13/03/2009. p. 08

RAMIREZ, H. Paradigmas da açorianidade no Rio Grande do Sul: a obra pioneira dos lusodescendentes. Porto Alegre: Editora Caravela, 2005.

ROCHA, S I D da (Org.). Açorianos no Rio Grande do Sul-Brasil II. Porto Alegre: Editora Caravela, 2007.

SANTOS, J. L. d. O que é cultura. São Paulo: Brasiliense, 1983.

SANTOS N R A dos. Taquari-Primeira cidade açoriana. In: ROCHA, S I D da (Org.). Açorianos no Rio Grande do Sul-Brasil II. Porto Alegre: ed. Caravela, 2007. p. 39-71.

SILVA, R da C. São José de Taquari - A história da minha terra. Porto Alegre: Edições Flama, 1972.

TAVARES, M D. Irmandades, Igrejas e devoção no sul do Império do Brasil. São Leopoldo: Editora Unisinos, 2008. 